\title{
Fatty acid amide hydrolase (FAAH) inhibition enhances memory acquisition through activation of PPAR- $\alpha$ nuclear receptors
}

\author{
Carmen Mazzola, ${ }^{1,2}$ Julie Medalie, ${ }^{1}$ Maria Scherma, ${ }^{1}$ Leigh V. Panlilio, ${ }^{1}$ \\ Marcello Solinas, ${ }^{3}$ Gianluigi Tanda, ${ }^{4}$ Filippo Drago, ${ }^{2}$ Jean Lud Cadet, ${ }^{5}$ \\ Steven R. Goldberg, ${ }^{1}$ and Sevil Yasar ${ }^{5,6,7}$
}

${ }^{1}$ Preclinical Pharmacology Section, Behavioral Neuroscience Research Branch, Intramural Research Program, NIDA, NIH, DHHS, Baltimore, Maryland 21224, USA; ${ }^{2}$ Department of Experimental and Clinical Pharmacology, Medical School, University of Catania, Catania 86022, Italy; ${ }^{3}$ Department Laboratoire de Biologie et Physiologie Cellulaires, CNRS-6187, Université de Poitiers, 86022 Poitiers, France; ${ }^{4}$ Psychobiology Section, Medications Discovery Research Branch, Intramural Research Program, NIDA, NIH, DHHS, Baltimore, Maryland 21224, USA; ${ }^{5}$ Molecular Neuropsychiatry Branch, Intramural Research Program, NIDA, NIH, DHHS, Baltimore, Maryland 21224, USA; ${ }^{6}$ Division of Geriatric Medicine and Gerontology, Department of Medicine, Johns Hopkins School of Medicine, Baltimore, Maryland 21224, USA

\begin{abstract}
Inhibitors of fatty acid amide hydrolase (FAAH) increase endogenous levels of anandamide (a cannabinoid $\mathrm{CB}_{1}$-receptor ligand) and oleoylethanolamide and palmitoylethanolamide (OEA and PEA, ligands for $\alpha$-type peroxisome proliferatoractivated nuclear receptors, PPAR- $\alpha$ ) when and where they are naturally released in the brain. Using a passive-avoidance task in rats, we found that memory acquisition was enhanced by the FAAH inhibitor URB597 or by the PPAR- $\alpha$ agonist WY14643, and these enhancements were blocked by the PPAR- $\alpha$ antagonist MK886. These findings demonstrate novel mechanisms for memory enhancement by activation of PPAR- $\alpha$, either directly by administering a PPAR- $\alpha$ agonist or indirectly by administering a FAAH inhibitor.
\end{abstract}

Peroxisome proliferator-activated receptor- $\alpha$ (PPAR- $\alpha$ ) is a ligandactivated transcriptional factor that regulates the expression of genes involved in lipid utilization, fatty acid oxidation, and inflammation (van Raalte et al. 2004; LoVerme et al. 2006). Immunolocalization studies of PPAR- $\alpha$ in the adult rat brain suggest that this nuclear receptor might have specific functions in regulating expression of genes involved in cholinergic neurotransmission and learning and memory processes (Moreno et al. 2004; Cimini et al. 2005). For example, there are high concentrations of PPAR- $\alpha$ receptors in the hippocampus and amygdala (Moreno et al. 2004). However, the potential involvement of PPAR- $\alpha$ in learning and memory processes has not been systematically investigated.

Endogenous ligands for PPAR- $\alpha$ include the lipid mediators $\mathrm{N}$-oleoylethanolamide (OEA) and $\mathrm{N}$-palmitoylethanolamide (PEA). In addition, anandamide ( $\mathrm{N}$-arachidonoylethanolamine), which has primarily been studied as an endogenous ligand for G-proteincoupled cannabinoid $\mathrm{CB}_{1}$ receptors that mediate the behavioral effects of cannabis and its active constituent $\Delta^{9}$-tetrahydrocannabinol (THC) (Devane et al. 1992; Solinas et al. 2008), has recently begun to receive attention as a potential endogenous PPAR- $\alpha$ ligand (O'Sullivan 2000; Mackie and Stella 2006; Sun et al. 2007). OEA has primarily been studied as a satiety factor (Rodriguez de Fonseca et al. 2001; Fu et al. 2003) and PEA as an anti-inflammatory factor (Kuehl et al. 1957; Calignano et al. 1998; Jaggar et al. 1998). OEA and PEA are structurally similar to anandamide but do not bind to or activate cannabinoid $\mathrm{CB}_{1}$ receptors. Anandamide, OEA,

${ }^{7}$ Corresponding author.

E-mail syasar@jhmi.edu; fax (410) 550-2513.

Article is online at http://www.learnmem.org/cgi/doi/10.1101//m.1145209. and PEA are all inactivated primarily by the intracellular serine enzyme, fatty acid amide hydrolase (FAAH) (Cravatt and Lichtman 2002; Fegley et al. 2005). Consequently, selective FAAH-inhibiting drugs such as cyclohexyl carbamic acid 3'-carbamoyl-3-yl ester (URB597) increase endogenous levels of anandamide, OEA, and PEA in the brain (Fegley et al. 2005; Piomelli et al. 2006).

In the present experiments, the effects of FAAH inhibition on learning and memory processes and the involvement of cannabinoid $\mathrm{CB}_{1}$ receptors and PPAR- $\alpha$ nuclear receptors in those effects were studied using a passive-avoidance procedure in rats. FAAH inhibition was accomplished by administering URB597. The effects of URB597 were studied alone and after pretreatment with the selective cannabinoid $\mathrm{CB}_{1}$ receptor antagonist/inverse agonist rimonabant (SR141716) and the selective PPAR- $\alpha$ antagonist MK886 (Kehrer et al. 2001). In addition, the effects of direct activation of PPAR- $\alpha$ receptors were studied by administering [[4chloro-6-[(2,3-dimethylphenyl)amino]-2-pyrimidinyl]thio]acetic acid (WY14643), a selective PPAR- $\alpha$ agonist (Forman et al. 1997; Krey et al. 1997), and the effects of direct activation of cannabinoid $\mathrm{CB}_{1}$ receptors was studied by administering THC.

Male Sprague-Dawley rats (Charles River Laboratories, Inc.) weighing 250-280 g were housed two per cage with food and water available ad libitum in a temperature- and humidity-controlled room with a 12-h light/dark cycle. Experimental procedures were conducted during the light phase. Each animal was adapted to daily handling for $1 \mathrm{wk}$ before the start of experiments. All experiments were conducted in accordance with the guidelines of the Institutional Care and Use Committee of the Intramural Research Program, National Institute on Drug Abuse (NIDA) and the Guide for Care and Use of Laboratory Animals (National Research Council 2003). 
The procedure used to study learning and memory was adapted from Mazzola et al. (2003). The two-compartment stepthrough apparatus (MED Associates model ENV-010MC) consisted of an illuminated compartment and a dark compartment, separated by a guillotine door. The illumination (measured with a Sekonic light meter, model L-308-B) was $\sim 172$ lux in the center of the light compartment and $\sim 5$ lux in the dark compartment facing the doorway. In the first session, an adaptation trial was conducted by placing the rat into the illuminated compartment facing away from the dark compartment; after 60 sec the guillotine door was opened, allowing the rat to enter the dark compartment. The latency for the rat to fully enter the dark compartment was recorded. The guillotine door was closed once the dark compartment was entered, then the rat was returned to its home cage.

During the learning trial, conducted $24 \mathrm{~h}$ after the habituation trial, rats were again placed in the illuminated compartment and the guillotine door was opened after $60 \mathrm{sec}$; when the rat entered the dark compartment, the door was closed and a scrambled foot shock $(0.5 \mathrm{~mA}$ and $2 \mathrm{sec})$ was delivered to the grid floor. The rat was then returned to its home cage. Several rats that returned to the light compartment before the door finished closing during this learning trial were dropped from the study. Twenty-four hours after the learning trial, a retention test was performed by placing the rat in the illuminated compartment with the door open, then measuring the latency for complete entry into the dark compartment. No shock was delivered during the test. The test session ended after $300 \mathrm{sec}$ if the rat did not enter the dark compartment.

Drugs were administered either before or immediately after the learning trial (to assess effects on memory acquisition and consolidation, respectively), or before the retention test (to assess effects on memory retrieval). URB597 (Kadmus) and MK886 (Tocris) were dissolved in 20\% DMSO and sterile water. WY14643 (Tocris) was dissolved in 70\% DMSO and sterile water. THC and rimonabant (SR141716) (NIDA, NIH) were dissolved in 2\% Tween 80, 2\% ethanol, and sterile water. Scopolamine (Tocris) was dissolved in sterile water. All drugs were injected intraperitoneally (i.p.) in a volume of $1 \mathrm{~mL} / \mathrm{kg}$.

During the adaptation and learning trials, all vehicle control and drug groups entered the dark compartment rapidly, and latencies to enter the dark compartment did not differ significantly between any of the groups and their vehicle control groups during these phases (Figs. $1 \mathrm{~A}$ and $2 \mathrm{~A})$. When scopolamine $(0.5$ $\mathrm{mg} / \mathrm{kg}$ ) was given $30 \mathrm{~min}$ before the learning trial, latencies to enter the dark compartment during the retention test $24 \mathrm{~h}$ later were markedly decreased ( $t$-test $t_{(13)}=2.65, P<0.05$ ), confirming that passive-avoidance learning in this procedure was sensitive to impairment by an amnesic agent (Fig. 1C).

The FAAH inhibitor URB597 (0.1-1.0 mg/kg), injected $40 \mathrm{~min}$ before the learning trial, had a significant enhancing effect on memory acquisition, increasing the latency to enter the dark compartment during the retention test $24 \mathrm{~h}$ later (Fig. 1C; ANOVA $\left.F_{(3,79)}=5.15, P<0.003\right)$. Similarly, the PPAR- $\alpha$ synthetic agonist WY14643 (10-40 mg/kg), injected $10 \mathrm{~min}$ before the learning trial, also had a significant enhancing effect on memory acquisition (Fig. 1C; ANOVA $F_{(3,51)}=4.82, P<0.005$ ). These enhancing effects of URB597 and WY 14643 were only seen when they were given before the learning trial, not when they were given immediately after the learning trial (to test for effects on memory consolidation; Fig. 1D) or when they were given 40 min (URB597) or 10 min (WY14643) before the retention test (to test for effects on memory retention; Fig. 1E). In contrast, the CB1 receptor agonist
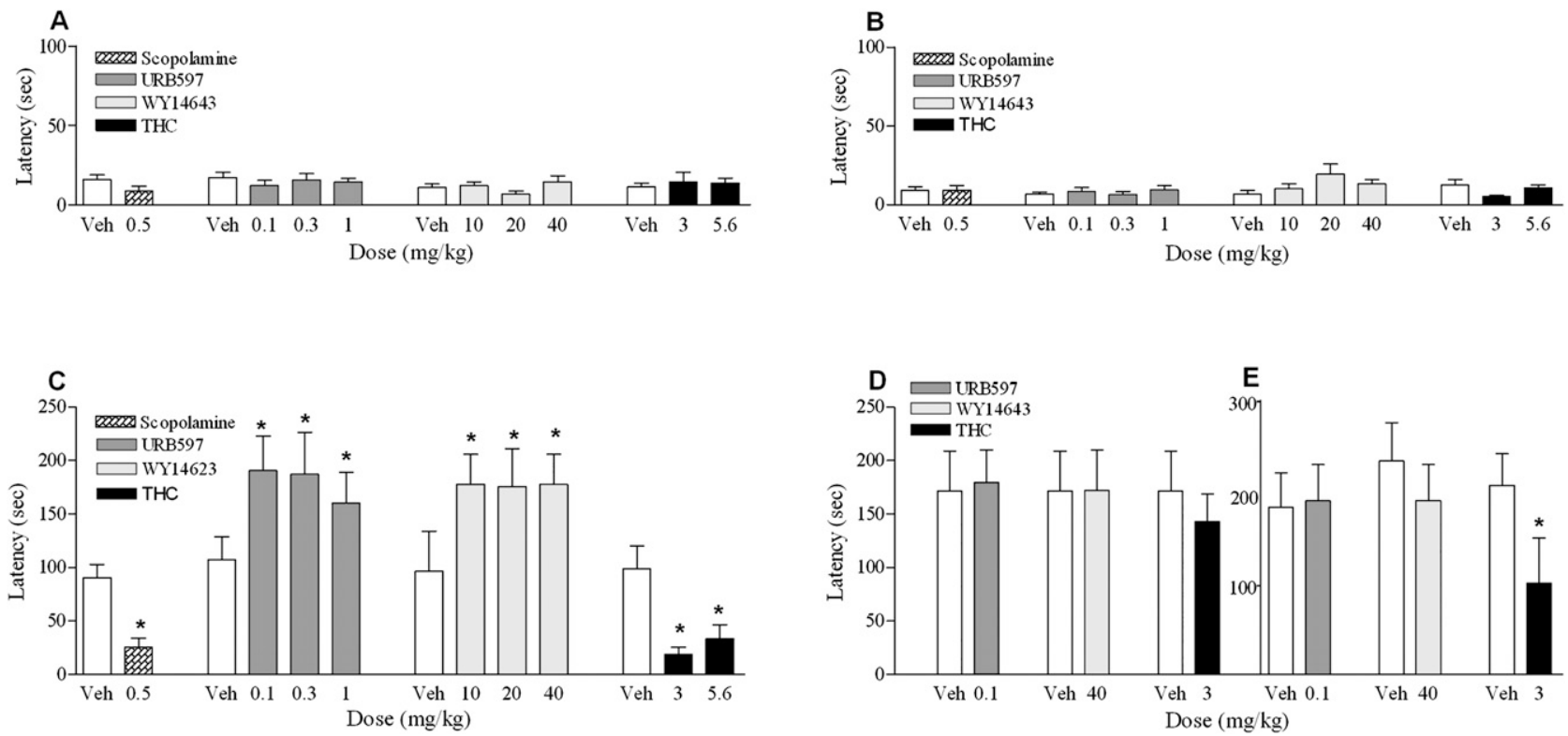

Figure 1. Effects of drugs on memory acquisition, consolidation, and retrieval. Data are expressed as mean latency (sec) \pm SEM to enter the dark compartment. ( $A-C)$ Show latencies during the adaptation trial $(A)$, learning trial $(B)$, and retention test $(C)$ for rats that received a drug or vehicle injection only before the learning trial. None of the groups differed from vehicle controls during the adaptation or learning trials. During the retention test, performed $24 \mathrm{~h}$ after the learning trial, rats that had received scopolamine or THC before the learning trial had significantly shorter latencies than control rats, indicating that these drugs impaired memory acquisition. In contrast, latencies were significantly higher than controls in rats that had received URB597 or WY14643 before the learning trial, indicating that these drugs enhanced memory acquisition. (D) Panel shows that neither URB597 nor WY14643 had a significant effect on latencies during the test in groups that received these drugs immediately after the learning trial or (E) 20 or 40 min, respectively, before the test, indicating that these drugs did not alter memory consolidation or retention. Latencies during the habituation and learning trials for the rats in $D$ are not shown, but were similar to those seen in $A$ and $B$. From left to right, Ns for the bars in $A, B$, and $C$ were: $7,8,10,10,11,7,10$, 8,8 , and 7 ; in $D: 10,10,10,10,10$, and 9 ; and in $E: 10,9,10,8,10$, and 10. $\left.{ }^{*}\right) P<0.05$ compared with vehicle control (VEH), paired comparisons performed with Tukey procedure. 

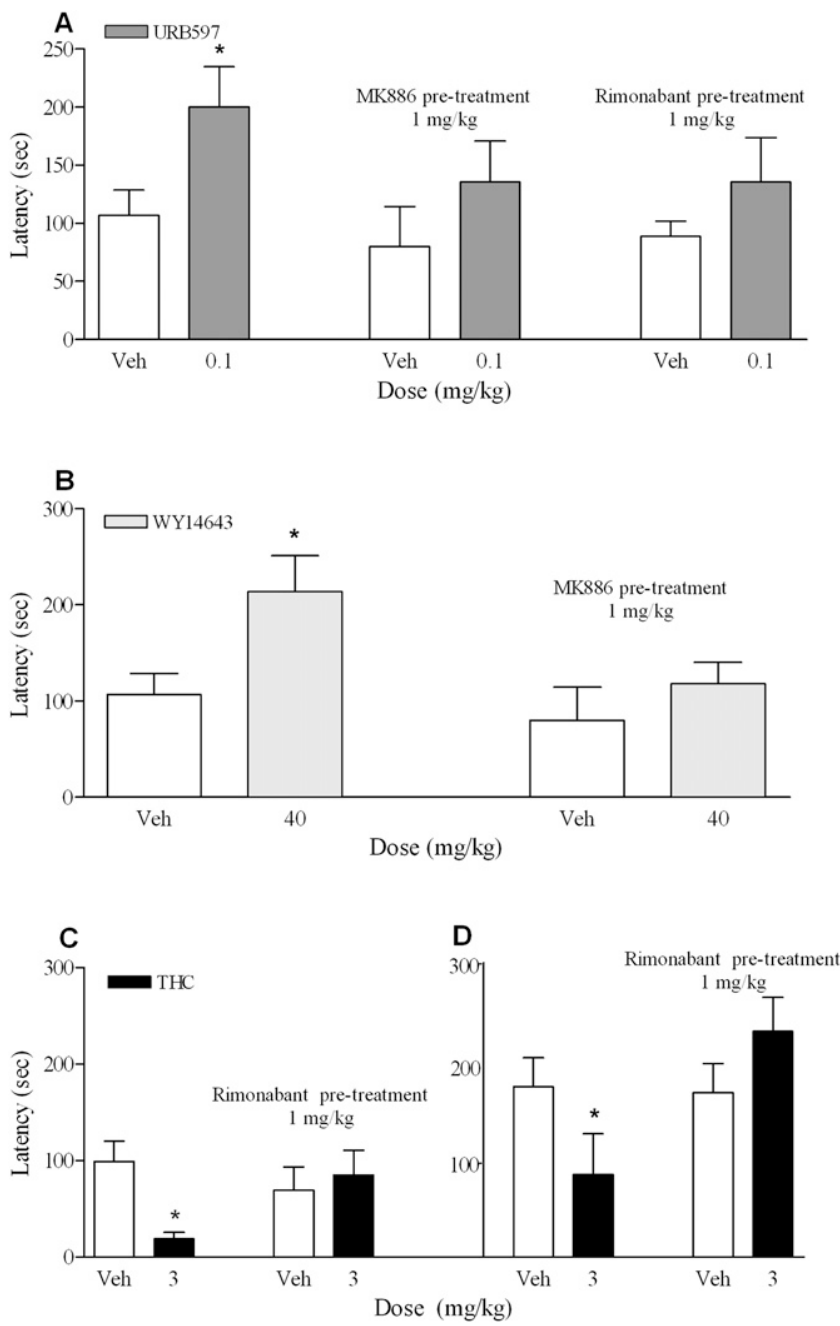

Figure 2. Blockade of URB597-, WY14643-, and THC-induced effects on memory acquisition. Data are expressed as mean latency (sec) \pm SEM to enter the dark compartment during the retention test. Blockade of PPAR- $\alpha$ by MK886 (1 mg/kg) reversed the enhancement of memory acquisition by URB597 (0.1 mg/kg; A) and WY14643 (40 mg/kg; B). Blockade of $C B_{1}$ reversed the enhancement produced by URB597 and also reversed the deficits induced by $\mathrm{THC}(3 \mathrm{mg} / \mathrm{kg})$ when given before the learning trial $(C)$ or before the retention test $(D)$. From left to right, Ns for the bars in $A$ were: $10,10,8,8,8$, and 10 ; in $B: 10,7,8$, and 8 ; in $C: 10,7$, 8 , and 10; and in $D: 9,8,9$, and 9 . (*) $P<0.05$ compared with vehicle control (VEH), paired comparisons performed with Tukey procedure.

THC (3 and $5.6 \mathrm{mg} / \mathrm{kg}$ ) injected $30 \mathrm{~min}$ before the learning trial significantly impaired memory acquisition (Fig. 1 C; $F_{(2,22)}=20.85$, $P<0.05$ ), and this impairment (THC $3 \mathrm{mg} / \mathrm{kg}$ ) was reversed by pretreatment with $1 \mathrm{mg} / \mathrm{kg}$ rimonabant (Fig. 2C; ANOVA, interaction of pretreatment and treatment, $\left.F_{(1,36)}=7.65, P<0.05\right)$. THC $(3$ $\mathrm{mg} / \mathrm{kg}$ ) also impaired retention when given $30 \mathrm{~min}$ before the test $\left(t\right.$-test $t_{(18)}=2.2, P<0.05 ;$ Fig. $\left.1 \mathrm{E}\right)$, and this impairment was reversed by $1 \mathrm{mg} / \mathrm{kg}$ rimonabant (Fig. 2D; ANOVA, interaction of pretreatment and treatment, $\left.F_{(2,22)}=5.51, P<0.05\right)$.

Further testing demonstrated that the memory-enhancing effects of URB597 were blocked when rats were pretreated with either $1.0 \mathrm{mg} / \mathrm{kg}$ of the PPAR- $\alpha$ antagonist MK886 (ANOVA, interaction of pretreatment and treatment, $F_{(1,32)}=6.29, P<$ 0.05 ) or $1.0 \mathrm{mg} / \mathrm{kg}$ of the CB1-receptor antagonist rimonabant (ANOVA, interaction of pretreatment and treatment, $F_{(1,34)}=8.76$, $P<0.05) 60 \mathrm{~min}$ before the learning trial (Fig. 2A). The enhance- ments produced by giving WY14643 before the learning trial were also blocked by $1.0 \mathrm{mg} / \mathrm{kg}$ MK886 (Fig. 2B; ANOVA, interaction of pretreatment and treatment, $\left.F_{(1,29)}=5.36, P<0.05\right)$. Neither 1.0 $\mathrm{mg} / \mathrm{kg}$ of MK886 nor $1.0 \mathrm{mg} / \mathrm{kg}$ of rimonabant affected learning when given with the vehicles for URB597 or WY14643 before the learning trial (Fig. 2A,B).

In a second set of experiments, designed to assess the possibility that URB597, WY14643, or THC might induce motor or emotional effects that could influence the acquisition or expression of the passive-avoidance response, we also investigated the effects of these drugs on locomotor activity and anxietyrelated behavior of naïve male Sprague-Dawley rats in an openfield test (Prut and Belzung 2003) and a light/dark test (Scherma et al. 2008). Open-field arenas (Med Associates) were enclosed in sound-attenuation chambers, with two arenas in each chamber and a small light on the wall of the chamber providing illumination of $\sim 2.6$ lux. The open-field arenas $(41 \times 41 \times 32 \mathrm{~cm})$ were composed of clear acrylic and had sawdust bedding on the floor. Activity was measured during 5-min sessions (a duration similar to that used in the learning trial and retention test of the passiveavoidance procedure) with a $16 \times 16$ array of photobeams using Med Associates Open Field Activity Software.

The measures analyzed for the open-field test were: distance traveled, number of ambulatory episodes, average speed within ambulatory episodes, number of stereotypy counts, number of vertical counts, number of jump counts, number of entries into a center zone (defined as a square covering 1/9th of the field), and time spent within $5 \mathrm{~cm}$ of the walls of the field (thigmotaxis), as shown in Figure 3. At the doses tested, URB597, WY14643, and THC had little or no effect on general activity (Fig. 3A-F) or anxiety-related behavior (i.e., center-zone entries and thigmotaxis) (Fig. 3G,H; Prut and Belzung 2003) in the open field. URB597 $(0.1 \mathrm{mg} / \mathrm{kg})$ produced a significant increase in jumping (Fig. 3G; $\left.F_{(3,24)}=7.59, P<0.001\right)$. WY14643 $(20 \mathrm{mg} / \mathrm{kg})$ produced a marginal decrease in distance traveled (Fig. 3A; ANOVA $F_{(3,30)}=$ 8.34, $P<0.056$ ). All other measures were unaffected.

The light/dark test utilized the same two-compartment stepthrough apparatus (MED Associates model ENV-010MC) used for the passive avoidance studies, with the same levels of illumination. To parallel the procedure used to test learning and memory in the present study, there was a 5-min adaptation trial the day before the test trial; this differed from the procedure used in our previous study, in which URB597 had significant anxiolytic effects, in that no adaptation trial was conducted in the earlier study (Scherma et al. 2008). During both the adaptation and test trials, rats were placed in the illuminated compartment facing away from the dark compartment; after $60 \mathrm{sec}$, the guillotine door was opened, allowing the rat to enter the dark compartment. During the 5-min test, time spent (seconds) in the light compartment and the level of activity (counts/minute) were measured. At the doses tested, neither URB597 nor WY 14643 had a significant effect on time spent in the light compartment or on the level of activity compared with vehicle-treated controls. The mean \pm SEM numbers of seconds spent in the light compartment were $129.9 \pm 7.2$ for URB597, $131 \pm 14.9$ for URB597's vehicle, 102.2 \pm 11.1 for WY 14643 , and 128.6 for WY 14643's vehicle. The mean \pm SEM numbers of activity counts per minute were $49.8 \pm 2.7$ for URB597, $50.7 \pm 5.4$ for URB597's vehicle, $41.7 \pm 4.0$ for WY 14643 , and $50.0 \pm 3.8$ for WY 14643's vehicle (all $P$ s $>0.13$ ). The failure to see significant anxiolytic effects of URB597, as we did in previous experiments using the light/dark test (Scherma et al. 2008), may be due to the procedural change of allowing an adaptation trial prior to the test trial, which would minimize stress during testing in the present experiments.

The results of this study indicate that manipulations of PPAR- $\alpha$ activity can have positive effects on memory acquisition 

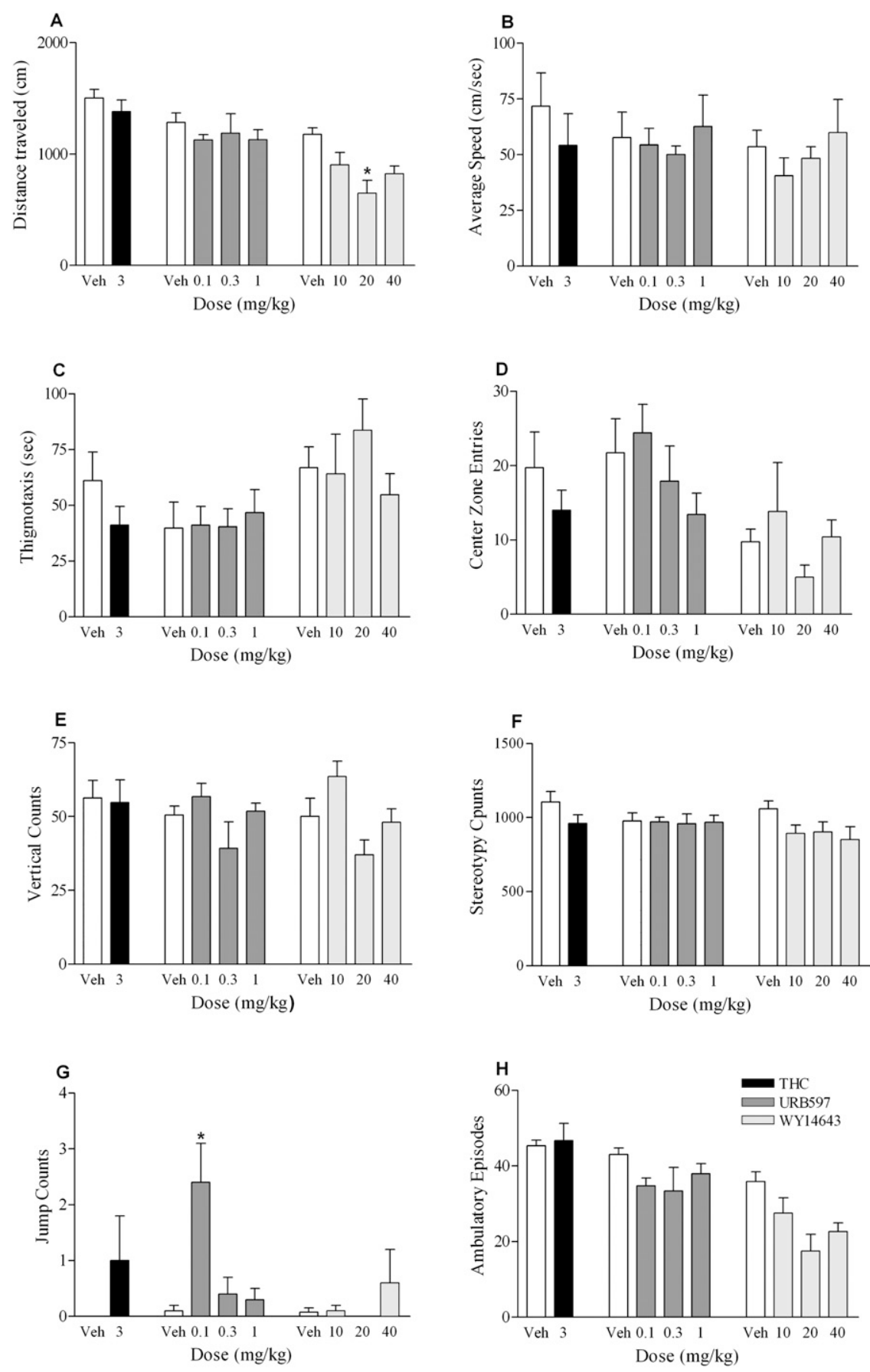

Figure 3. Effects of drugs on open-field behavior. Data are expressed as mean $\pm \mathrm{SEM}$. (A) Distance traveled, $(B)$ average speed, (C) time spent within $5 \mathrm{~cm}$ of a wall (thigmotaxis), $(D)$ center-zone entries, $(E)$ vertical counts, $(F)$ stereotypy counts, $(G)$ jump counts, and $(H)$ ambulatory episodes. Although URB597 $(0.1 \mathrm{mg} / \mathrm{kg})$ produced a small but significant increase in jumping $(G)(P<0.05)$ and WY14643 $(20 \mathrm{mg} / \mathrm{kg})$ produced a marginal decrease in distance traveled $(A)(P<0.056)$ compared with vehicle control $(\mathrm{VEH})$, none of the other treatments had a significant effect on any of these measures of general activity $(A, B, E, H)$ or anxiety-related behavior $(C, D)$. From left to right, $N$ s for the bars in all panels were: 7 , $7,7,7,7,7,13,6,6$, and 7 . All paired comparisons performed with Tukey procedure.

in a passive-avoidance procedure. These effects were obtained when a synthetic PPAR- $\alpha$ agonist (WY14643) was administered, or when levels of endogenous lipid amides that act at $\mathrm{CB}_{1}$ and PPAR- $\alpha$ receptors were increased by the FAAH inhibitor URB597. In both of these cases, the memory-enhancing effects were blocked by pretreatment with the selective PPAR- $\alpha$ antagonist, MK886. These results are consistent with the recent finding that FAAH inhibition can enhance place-memory acquisition in the water-maze procedure (Varvel et al. 2007) and extend them by demonstrating the role of PPAR- $\alpha$ in such effects.

URB597 and WY14643 did not affect memory consolidation or retrieval when given immediately after the learning trial or before the retention test, respectively. The possibility remains that they could affect consolidation under dosing, training, or testing parameters other than the ones used. It seems unlikely that the onset of action of URB597 was outside the window of consolidation, since systemically administered URB597 can almost completely block FAAH activity within 15 min (Kathuria et al. 2003). In addition, administration of WY14643, which is likely to produce a more rapid and direct activation of PPAR- $\alpha$ within the window of consolidation, was also ineffective.

Neither the enhanced memory acquisition produced by URB597 and WY14643 nor the impaired memory acquisition produced by THC can be attributed to changes in general activity, exploration, arousal, or anxiety, since URB597, WY14643, and THC had little or no effect on any open-field activity measure, and URB597 and WY14643 had no significant effect on anxiety or activity in the light-dark box. Furthermore, none of these drugs altered latencies to enter the dark compartment during the learning trial of the passive-avoidance procedure. The fact that we did not observe significant anxiolytic effects of URB597 like those we obtained in previous experiments using the light/dark test (Scherma et al. 2008) may be due to the procedural change of allowing an adaptation trial prior to the test trial, which would minimize stress during testing (Haller et al. 2009). Some of the endogenous fatty acids affected by FAAH inhibition (i.e., OEA and anandamide) also affect signaling at the TRPV1 receptor (Ahern 2003; Starowicz et al. 2007; Rubino et al. 2008). TRPV1 knock out mice show reduced anxiety and fear-based learning compared with wildtype littermates (Marsch et al. 2007), and systemic administration of high doses of anandamide may induce TRPV1mediated anxiety-like effects or disruptions in behavior when given in combination with a FAAH inhibitor (Scherma et al. 2008; Panlilio et al. 2009). However, systemic administration of a FAAH inhibitor alone has not been shown to produce such effects (Scherma et al. 2008; Panlilio et al. 2009). 
Systemically administered cannabinoid $\mathrm{CB}_{1}$-receptor agonists such as THC can cause learning and memory impairments in passive-avoidance tests in rodents (present experiments) (Castellano et al. 1997, 2003; Mishima et al. 2001; Niyuhire et al. 2007). This suggests that indirect cannabinergic effects of URB597 (i.e., increased anandamide levels) could produce a learning impairment. However, URB597 only increases anandamide levels at those neuronal sites and brain areas where anandamide is synthesized and released, producing a neuron-specific activation of $\mathrm{CB}_{1}$ receptors in those areas, unlike the global activation of all $\mathrm{CB}_{1}$ receptors everywhere in the brain produced by systemic administration of $\mathrm{CB}_{1}$ agonists such as THC. Thus, it is possible that activation of $\mathrm{CB}_{1}$ receptors at specific neuronal sites in selective areas of the brain, as would be expected with URB597, does not impair learning and memory. In contrast, although this hypothesis could not be tested in the present study, the fact that the effects of URB597 were reversed by the $\mathrm{CB}_{1}$ antagonist/inverse agonist rimonabant may indicate that selective activation of $\mathrm{CB}_{1}$ receptors can produce synergistic effects with PPAR- $\alpha$. These results are consistent with recent findings that joint stimulation of PPAR- $\alpha$ and $\mathrm{CB}_{1}$ receptors produces synergistic antinociceptive effects on peripheral pain, that these effects are reversed by rimonabant (Russo et al. 2007), and that antinociceptive effects of URB597 on peripheral pain can be blocked by PPAR- $\alpha$ antagonism (Sagar et al. 2008). Further studies are needed to determine whether synergistic enhancement of learning and memory can be achieved with local coadministration of naturally occurring endogenous ligands for $\mathrm{CB}_{1}$ receptors (anandamide) and PPAR- $\alpha$ (OEA and PEA), whose brain levels are all increased by FAAH inhibition.

It is well known that PPAR- $\alpha$ receptors are intimately involved in inflammatory processes (e.g., Combs et al. 2001) and in disruptions in glucose metabolism (e.g., Guerre-Millo et al. 2000) that may contribute to cognitive decline with Alzheimer's disease. PPAR- $\alpha$ activation reduces elevated glucose levels by improving insulin sensitivity (Guerre-Millo et al. 2000) and lowers levels of proinflammatory cytokines in aged animals (Poynter and Daynes 1998). PPAR- $\alpha$ receptors are also involved in regulation of the biosynthesis of acetylcholine (de la Monte and Wands 2006), and they are present in relatively large numbers in memory-related brain areas (Moreno et al. 2004). Polymorphisms in the PPAR- $\alpha$ gene are associated with increased risk for Alzheimer's disease (Brune et al. 2003). In the present experiments we show that the FAAH inhibitor URB597 and the PPAR- $\alpha$ agonist WY14643 can acutely enhance memory acquisition through actions involving PPAR- $\alpha$. These findings provide novel mechanisms for cognitive enhancement either by synergistic activation of PPAR- $\alpha$ and cannabinoid $\mathrm{CB}_{1}$ receptors by $\mathrm{FAAH}$ inhibition or by direct activation of PPAR- $\alpha$ by administration of selective PPAR- $\alpha$ agonists. The findings with FAAH inhibition further suggest a new approach for developing medications that work indirectly by enhancing the actions of endogenous lipid amide mediators where they are synthesized and released.

\section{Acknowledgments}

This research was supported by the Intramural Research Program of the NIH, National Institute on Drug Abuse. We thank Zuzana Justinova for help with preparing the figures and comments on the manuscript.

\section{References}

Ahern, G.P. 2003. Activation of TRPV1 by the satiety factor oleoylethanolamide. J. Biol. Chem. 278: 30429-30434.

Brune, S., Kölsch, H., Ptok, U., Majores, M., Schulz, A., Schlosser, R., Rao, M.L., Maier, W., and Heun, R. 2003. Polymorphism in the peroxisome proliferator-activated receptor $\alpha$ gene influences the risk for Alzheimer's disease. J. Neural Transm. 110: 1041-1050.

Calignano, A., La Rana, G., Giuffrida, A., and Piomelli, D. 1998. Control of pain initiation by endogenous cannabinoids. Nature 394: 277-281.

Castellano, C., Cabib, S., Palmisano, A., Di Marzo, V., and Puglisi-Allegra, S. 1997. The effects of anandamide on memory consolidation in mice involve both D1 and D2 dopamine receptors. Behav. Pharmacol. 8: 707-712.

Castellano, C., Rossi-Arnaud, C., Cestari, V., and Costanzi, M. 2003. Cannabinoids and memory: Animal studies. Curr. Drug Target. CNS Neurol. Disord. 2: 389-402.

Cimini, A., Benedetti, E., Cristiano, L., Sebastiani, P., D’Amico, M.A., D'Angelo, B., and Di Loreto, S. 2005. Expression of peroxisome proliferator-activated receptors (PPARs) and retinoic acid receptors (RXRs) in rat cortical neurons. Neuroscience 130: 325-337.

Combs, C.K., Bates, P., Karlo, J.C., and Landreth, G.E. 2001. Regulation of $\beta$-amyloid stimulated proinflammatory responses by peroxisome proliferator-activated receptor $\alpha$. Neurochem. Int. 39: 449-457.

Cravatt, B.F. and Lichtman, A.H. 2002. The enzymatic inactivation of the fatty acid amide class of signaling lipids. Chem. Phys. Lipids 121: 135-148.

de la Monte, S.M. and Wands, J.R 2006. Molecular indices of oxidative stress and mitochondrial dysfunction occur early and often progress with severity of Alzheimer's disease. J. Alzheimers Dis. 9: 167-181.

Devane, W.A., Hanus, L., Breuer, A., Pertwee, R.G., Stevenson, L.A., Griffin, G., Gibson, D., Mandelbaum, A., Etinger, A., and Mechoulam, R. 1992. Isolation and structure of a brain constituent that binds to the cannabinoid receptor. Science 258: 1946-1949.

Fegley, D., Gaetani, S., Duranti, A., Tontini, A., Mor, M., Tarzia, G., and Piomelli, D. 2005. Characterization of the fatty acid amide hydrolase inhibitor cyclohexyl carbamic acid 3'-carbamoyl-biphenyl-3-yl ester (URB597): Effects on anandamide and oleoylethanolamide deactivation. J. Pharmacol. Exp. Ther. 313: 352-358.

Forman, B.M., Chen, J., and Evans, R.M. 1997. Hypolipidemic drugs, polyunsaturated fatty acids, and eicosanoids are ligands for peroxisome proliferator-activated receptors $\alpha$ and $\delta$. Proc. Natl. Acad. Sci. 94: 4312-4317.

Fu, J., Gaetani, S., Oveisi, F., Lo Verme, J., Serrano, A., Rodriguez De Fonseca, F., Rosengarth, A., Luecke, H., Di Giacomo, B., Tarzia, G., et al. 2003. Oleylethanolamide regulates feeding and body weight through activation of the nuclear receptor PPAR- $\alpha$. Nature 425: 90-93.

Guerre-Millo, M., Gervois, P., Raspé, E., Madsen, L., Poulain, P., Derudas, B., Herbert, J.M., Winegar, D.A., Willson, T.M., Fruchart, J.C., et al. 2000. Peroxisome proliferator-activated receptor $\alpha$ activators improve insulin sensitivity and reduce adiposity. J. Biol. Chem. 275: 16638-16642.

Haller, J., Barna, I., Barsvari, B., Gyimesi Pelczer, K., Yasar, S., Panlilio, L.V., and Goldberg, S.R. 2009. Interactions between environmental aversiveness and the anxiolytic effects of enhanced cannabinoid signaling by FAAH inhibition rats. Psychopharmacology doi: 10.1007/ s00213-009-1494-7.

Jaggar, S.I., Hasnie, F.S., Sellaturay, S., and Rice, A.S. 1998. The antihyperalgesic actions of the cannabinoid anandamide and the putative CB2 receptor agonist palmitoylethanolamide in visceral and somatic inflammatory pain. Pain 76: 189-199.

Kathuria, S., Gaetani, S., Fegley, D., Valino, F., Duranti, A., Tontini, A., Mor, M., Tarzia, G., Rana, G.L., Calignano, A., et al. 2003. Modulation of anxiety through blockade of anandamide hydrolysis. Nat. Med. 9: 76-81.

Kehrer, J.P., Biswal, S.S., La, E., Thuillier, P., Datta, K., Fischer, S.M., and Vanden Heuvel, J.P. 2001. Inhibition of peroxisome-proliferatoractivated receptor (PPAR) $\alpha$ by MK886. Biochem. J. 356: 899-906.

Krey, G., Braissant, O., L'Horset, F., Kalkhoven, E., Perroud, M., Parker, M.G., and Wahli, W. 1997. Fatty acids, eicosanoids, and hypolipidemic agents identified as ligands of peroxisome proliferator-activated receptors by coactivator-dependent receptor ligand assay. Methods Enzymol. 11: 779-791.

Kuehl, F.A., Jacob, T.A., Ganley, O.H., Ormond, R.E., and Meisinger, M.A.P. 1957. The identification of $\mathrm{N}$-(2-hydroxyethyl)-palmitamide as a naturally occurring anti-inflammatory agent. J. Am. Chem. Soc. 79: 5577-5578.

LoVerme, J., Russo, R., La Rana, G., Fu, J., Farthing, J., Mattace-Raso, G., Meli, R., Hohmann, A., Calignano, A., and Piomelli, D. 2006. Rapid broad-spectrum analgesia through activation of peroxisome proliferator-activated receptor- $\alpha$. J. Pharmacol. Exp. Ther. 319: 1051-1061.

Mackie, K. and Stella, N. 2006. Cannabinoid receptors and endocannabinoids: Evidence for new players. AAPS J. 8: 298-306.

Marsch, R., Foeller, E., Rammes, G., Bunck, M., Kössl, M., Holsboer, F., Zieglgänsberger, W., Landgraf, R., Lutz, B., and Wotjak, C.T. 2007. Reduced anxiety, conditioned fear, and hippocampal long-term potentiation in transient receptor potential vanilloid type 1 receptordeficient mice. J. Neurosci. 27: 832-839. 
Mazzola, C., Micale, V., and Drago, F. 2003. Amnesia induced by $\beta$-amyloid fragments is counteracted by cannabinoid CB1 receptor blockade. Eur. J. Pharmacol. 477: 219-225.

Mishima, K., Egashira, N., Hirosawa, N., Fujii, M., Matsumoto, Y., Iwasaki, K., and Fujiwara, M. 2001. Characteristics of learning and memory impairment induced by $\delta 9$-tetrahydrocannabinol in rats. Jpn. J. Pharmacol. 87: 297-308.

Moreno, S., Farioli-Vecchioli, S., and Ceru, M.P. 2004. Immunolocalization of peroxisome proliferator-activated receptors and retinoid X receptors in the adult rat CNS. Neuroscience 123: 131-145.

Niyuhire, F., Varvel, S.A., Martin, B.R., and Lichtman, A.H. 2007. Exposure to marijuana smoke impairs memory retrieval in mice. J. Pharmacol. Exp. Ther. 322: 1067-1075.

O'Sullivan, S.E. 2007. Cannabinoids go nuclear: Evidence for activation of peroxisome proliferator-activated receptors. Br. J. Pharmacol. 152: 576582.

Panlilio, L.V., Mazzola, C., Medalie, J., Hahn, B., Justinova, Z., Drago, F., Cadet, J.L., Yasar, S., and Goldberg, S.R. 2009. Anandamide-induced behavioral disruption through a vanilloid-dependent mechanism in rats. Psychopharmacology doi: 10.1007/s00213-008-1399-x.

Piomelli, D., Tarzia, G., Duranti, A., Tontini, A., Mor, M., Compton, T.R., Dasse, O., Monaghan, E.P., Parrott, J.A., and Putman, D. 2006. Pharmacological profile of the selective FAAH inhibitor KDS-4103 (URB597). CNS Drug Rev. 12: 21-38.

Poynter, M.E. and Daynes, R.A. 1998. Peroxisome proliferator-activated receptor $\alpha$ activation modulates cellular redox status, represses nuclear factor- $\kappa \mathrm{B}$ signaling, and reduces inflammatory cytokine production in aging. J. Biol. Chem. 273: 32833-32841.

Prut, L. and Belzung, C. 2003. The open field as a paradigm to measure the effects of drugs on anxiety-like behaviors: A review. Eur. J. Pharmacol. 463: $3-33$.

Rodriguez de Fonseca, F., Navarro, M., Gomez, R., Escuredo, L., Nava, F., Fu, J., Murillo-Rodriguez, E., Giuffrida, A., LoVerme, J., Gaetani, S., et al. 2001. An anorexic lipid mediator regulated by feeding. Nature 414: 209-212.
Rubino, T., Realini, N., Castiglioni, C., Guidali, C., Viganó, D., Marras, E., Petrosino, S., Perletti, G., Maccarrone, M., Di Marzo, V., et al. 2008. Role in anxiety behavior of the endocannabinoid system in the prefrontal cortex. Cereb. Cortex 18: 1292-1301.

Russo, R., Loverme, J., La Rana, G., Compton, T.R., Parrott, J., Durante, A., Tontini, A., Mor, M., Tarzia, G., Calignano, A., et al. 2007. The fatty acid amide hydrolase inhibitor URB597 (cyclohexylcarbamic acid 3'carbamoylbiphenyl-3-yl ester) reduces neuropathic pain after oral administration in mice. J. Pharmacol. Exp. Ther. 322: 236-242.

Sagar, D.R., Kendall, D.A., and Chapman, V. 2008. Inhibition of fatty acid amide hydrolase produces PPAR- $\alpha$-mediated analgesia in a rat model of inflammatory pain. Br. J. Pharmacol. 155: 1297-1306.

Scherma, M., Medalie, J., Fratta, W., Vadivel, S.K., Makriyannis, A., Piomelli, D., Mikics, E., Haller, J., Yasar, S., Tanda, G., et al. 2008. The endogenous cannabinoid anandamide has effects on motivation and anxiety that are revealed by fatty acid amide hydrolase (FAAH) inhibition. Neuropharmacol 54: 129-140.

Solinas, M., Goldberg, S.R., and Piomelli, D. 2008. The endocannabinoid system in brain reward processes. Br. J. Pharmacol. 154: 369-383.

Sun, Y., Alexander, S.P., Garle, M.J., Gibson, C.L., Hewitt, K., Murphy, S.P., Kendall, D.A., and Bennett, A.J. 2007. Cannabinoid activation of PPAR $\alpha$; a novel neuroprotective mechanism. Br. J. Pharmacol. 152: 734-743.

Starowicz, K., Nigam, S., and Di Marzo, V. 2007. Biochemistry and pharmacology of endovanilloids. Pharmacol. Ther. 114: 13-33.

van Raalte, D.H., Li, M., Pritchard, P.H., and Wasan, K.M. 2004. Peroxisome proliferator-activated receptor (PPAR)- $\alpha$ : A pharmacological target with a promising future. Pharm. Res. 21: 1531-1538.

Varvel, S.A., Wise, L.E., Niyuhire, F., Cravatt, B.F., and Lichtman, A.H. 2007. Inhibition of fatty-acid amide hydrolase accelerates acquisition and extinction rates in a spatial memory task. Neuropsychopharmacol 32: 1032-1041.

Received July 7, 2008; accepted in revised form February 17, 2009. 


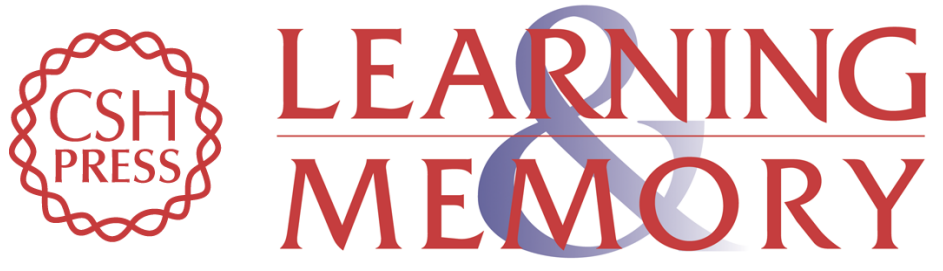

\section{Fatty acid amide hydrolase (FAAH) inhibition enhances memory acquisition through activation of PPAR- $\alpha$ nuclear receptors}

Carmen Mazzola, Julie Medalie, Maria Scherma, et al.

Learn. Mem. 2009, 16:

Access the most recent version at doi:10.1101//m.1145209

References This article cites 42 articles, 10 of which can be accessed free at:

http://learnmem.cshlp.org/content/16/5/332.full.html\#ref-list-1

License

Email Alerting Receive free email alerts when new articles cite this article - sign up in the box at the Service top right corner of the article or click here. 